JTRM | Vol. 2 | No. 2 | Tahun 2020

ISSN (P): 2715-3908 | ISSN (E): 2715-016X

DOI: https://doi.org/10.48182/jtrm.v2i2.66

\title{
Pendinginan Pengelasan menggunakan Metode SMAW pada Kekerasan Baja Karbon ST3 dengan Media Serbuk Semen Putih dan Beban Rockwell 100kgf
}

\author{
Muh Anhar ${ }^{1}$, Asep Ruchiyat ${ }^{2}$ \\ ${ }^{1,2}$ Perawatan dan Perbaikan Mesin Politeknik Negeri Ketapang \\ Email: anhar_dol@yahoo.com
}

\begin{tabular}{ll}
\hline \hline $\begin{array}{l}\text { Informasi } \\
\text { Artikel: }\end{array}$ & ABSTRAK \\
\hline
\end{tabular}

Received:

27 Juni 2020

Accepted:

25 September 2020

Available:

15 Oktober 2020
Pengelasan merupakan bagian tak terpisahkan dari pertumbuhan peningkatan industri karena memegang peran utama dalam rekayasa dan reparasi produksi logam. Penelitian ini bertujuan untuk mengetahui pengaruh media pendingin terhadap kekerasan logam las dan logam HAZ (heat Affected Zone) yang diuji kekerasan menggunakan metode Rockwell. Penelitian ini dilakukan pada material baja karbon rendah ST 37 yang dilas menggunakan elektroda E6013 diameter 2,6 mm dengan sambungan tumpul, kemudian diberikan pendinginan menggunakan serbuk semen putih.Logam las yang didinginkan dengan media serbuk semen putih memiliki kekerasan yang lebih keras,karena semen putih mengandung C2S yang sulit terhidrasi dan tidak memilikin sifat panas.Setelah dilakukan pengujian pada beberapa titik maka didapatlah hasil berupa nilai rata-rata dari spesimen raw material adalah 48,3 $\mathrm{HRB}$, pengelasan tanpa media isolator $=42,96 \mathrm{HRB}$ dan $\mathrm{HAZ}=46,4$ HRB.Spesimen yang menggunakan serbuk semen putih $=47,65 \mathrm{HRB}$ dan $\mathrm{HAZ}=48,2$ HRB.Dilihat dari fenomena tersebut dan semen putih memiliki nilai kekerasan yang lebih rendah dari pada udara, dimana HAZ pada kekerasan nilai pada udara 46,4 HRB dan nilai pada semen putih lebih tinggi yaitu 48,2 HRB.

\section{Kata Kunci:} ABSTRACT

SMAW welding Cooling Media Rockwell Method Hardness Test white cement powder
Welding is an inseparable part of the growth of industrial improvements because it plays a leading role in the engineering and repair of metal production. This study aims to determine the effect of cooling media on the hardness of weld metal and HAZ (heat Affected Zone) which tested hardness using the Rockwell method. This research was conducted on ST 37 low carbon steel material which was welded using $2.6 \mathrm{~mm}$ diameter E6013 electrode with blunt connection, then cooled using white cement powder. Welding metal cooled with white cement powder media has a harder hardness, because white cement contains C2S which is difficult to hydrate and does not have heat properties. After testing at several points, the result is an average value of raw material specimens is 48, $3 \mathrm{HRB}$, welding without isolator media $=42.96 \mathrm{HRB}$ and $H A Z=46.4 H R B$. Specimens using white cement powder $=47.65$ $H R B$ and $H A Z=48.2$ HRB. Seen from this phenomenon and white cement has a hardness value lower than air, where the $H A Z$ at the air value hardness was 46.4 HRB and the value of the white cement was higher at 48.2 HRB. 


\section{Pendahuluan}

Kualitas hasil pengelasan akan dipengaruhi diantaranya mesin las, bahan, prosedur, cara, arus dan juru las (Lawrence, H. Van Vlack,2003). Kualitas hasil pengelasan dapat diketahui dengan memberikan gaya atau beban pada hasil lasan. Gaya atau beban yang diberikan berupa pengujian tarik dan ketangguhan pada bahan tersebut (M. Zaenal Mawahib, Sarjito Jokosisworo, Hartono Yudo,2017). Las SMAW, proses pengelasan busur listrik dengan penggabungan atau perpaduan logam yang dihasilkan oleh panas 350 dari busur listrik yang dikeluarkan ujung elektroda terbungkus dan permukaan logam dasar yang dilas dengan menggunakan arus listrik sebagai sumber tenaga (V,Malau,2003),(Fajar Riyadi,Dony Setyawan,2013), (Abdul Hamid,2016). Jenis arus listrik yang digunakan ada 2 yaitu arus searah (DC) dan arus bolak-balik (AC) (H Sapitra, A Syarief,2014). SMAW merupakan teknik las dengan menggunakan arus listrik berbentuk burus arus dan elektroda berselaput dan banyak digunakan sistem pengelasan SMAW karena pengelasan ini sangat mudah dan lebih efektif (Helanianto,2017).Semen adalah hasil industri dari paduan bahan baku: batu kapur atau gamping sebagai bahan utama dan lempung atau tanah liat atau bahan pengganti lainnya dengan hasil akhir berupa padatan berbentuk bubuk atau bulk, tanpa memandang proeses pembuatannya, yang mengeras atau membatu pada pencampuran dengan air (Li Ke Yan,Xue Dongfeng,2009). Semen putih dijadikan pengujian pada pengelasan SMAW bertujuan mengetahui hasil dari nilai kekerasan yang diperoleh dengan pengujian Rockwell sebagai bentuk penganalisaan suatu media pendinginan (DA Tyagita,A Irawan,2016).

\section{METODE PENELITIAN}

Dalam penelitian ini digunakan metode pengujian kekerasan rockwell yang bertujuan untuk menghetahui besar tingkat kekerasan dari bahan material baja karbon ST 37 setelah melalui proses pendinginan serbuk semen putih sebagai kompositnya.

\section{HASIL DAN PEMBAHASAN}

Pemberian beban awal pada raw material untuk mengetahui angka awal kekerasan bahan sebelum bahan diberi beban yang lebih berat dengan beban 10kgf dengan waktu lama penekanan 5 detik,seperti pada Gambar 1. 


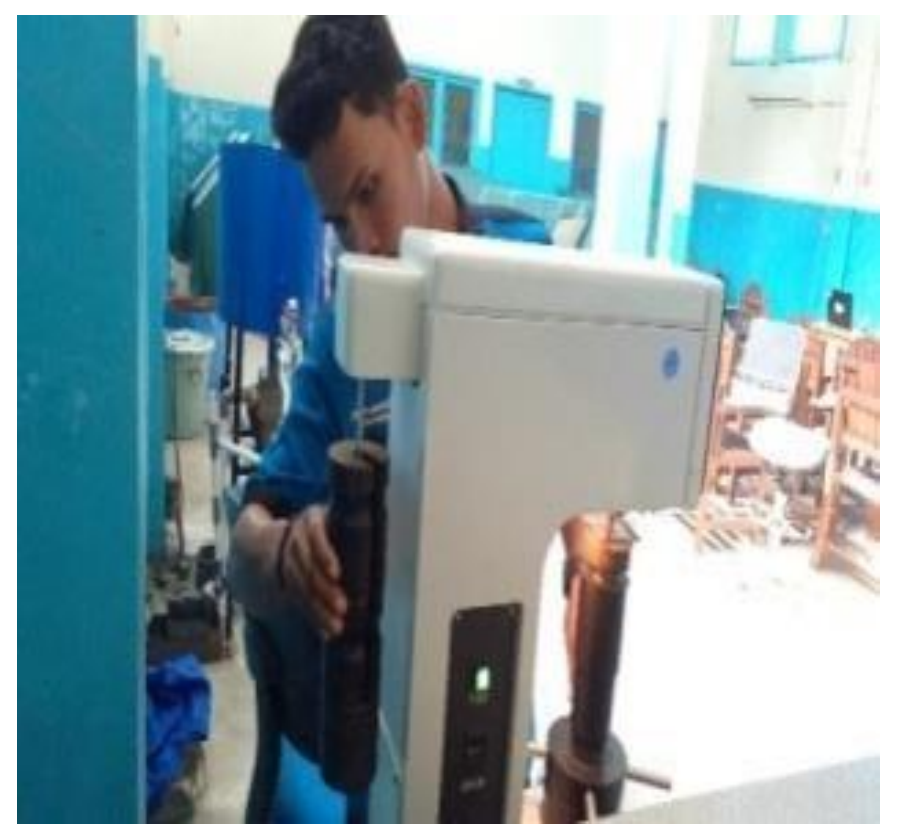

Gambar 1. Pemberian beban awal

Dengan diberikan beban akhir sebesar $100 \mathrm{kgf}$ dengan waktu tunggu 5 detik,didapat hasil berupa angka kekerasan pada mesin rockwell yang dapat dilihat pada Dial gauge.Baja karbon rendah memiliki kepekaan las yang rendah bila dibandingkan dengan baja karbon lainnya,atau dengan baja karbon paduan.Tetapi retak las pada baja karbon rendah dapat terjadi dengan mudah pada pengelasan plat tebal atau didalam baja tersebut terdapat belerang bebas yang cukup tinggi,namun hal ini bisa dihindari dengan pemanasan mula atau dilas dengan elektroda hydrogen rendah (Wiryosumarto,1996).

Dari proses dilakukan pada raw material didapatkan 10 titik data dengan pengujian kekerasan rockwell berat beban $100 \mathrm{Kgf}$,seperti pada tabel 1 di bawah ini.

Tabel 1. data raw material

\begin{tabular}{|c|c|c|}
\hline Titik & Daerah & $\begin{array}{c}\text { Spesimen } \\
\text { Raw Material }\end{array}$ \\
\hline 1 & \multirow{11}{*}{ Plat Baja Karbon Rendah } & 48 HRB \\
\hline 2 & & $47 \mathrm{HRB}$ \\
\hline 3 & & $47 \mathrm{HRB}$ \\
\hline 4 & & 49 HRB \\
\hline 5 & & $51 \mathrm{HRB}$ \\
\hline 6 & & 48 HRB \\
\hline 7 & & $47 \mathrm{HRB}$ \\
\hline 8 & & 49 HRB \\
\hline 9 & & 49 HRB \\
\hline 10 & & 48 HRB \\
\hline Rata - Rata & & 48.3 HRB \\
\hline
\end{tabular}

Raw material adalah salah satu spesimen uji yang akan digunakan untuk penelitian dan digunakan untuk perbandingan dengan spesimen uji las dengan serbuk semen putih dan 
udara, seperti pada Gambar grafik 2 di bawah ini.

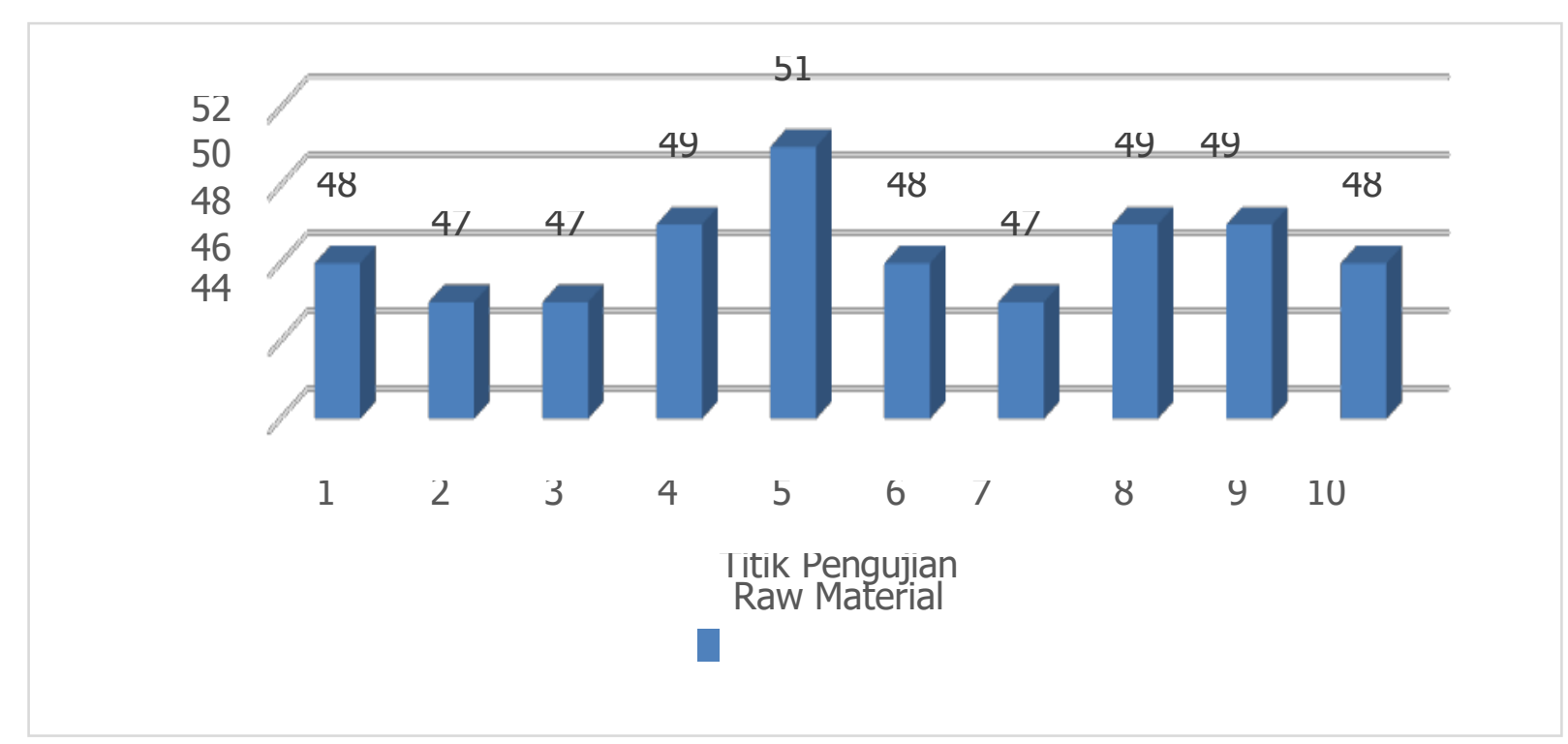

Gambar 2. Grafik Spesimen Raw Material

\subsection{Pengujian Hasil Las Dan Haz Tanpa Perlakuan}

Langkah pemberian beban awal pada logam las untuk mengetahui angka awal dari kekerasan bahan sebelum bahan diberi beban yang lebih berat.Untuk pemberian awal pada material diberi beban $10 \mathrm{kgf}$ dengan waktu lama penekanan 5 detik. Setelah pemberian beban awal selesai maka langkah selanjutnya yaitu memberikan beban akhir yaitu sebesar $100 \mathrm{kgf}$ dengan lama waktu tunggu selama 5 detik.

Saat proes penekan berlangsung pastikan benda uji benar benar dalam posisi yang pas dan tidak bergerak,ini yang akan menyebabkan angka pengukuran berubah pada saat penekanan jika posisi benda uji tidak dalam posisi sejajar, dapat dilihat pada Dial gauge Gambar 3. 


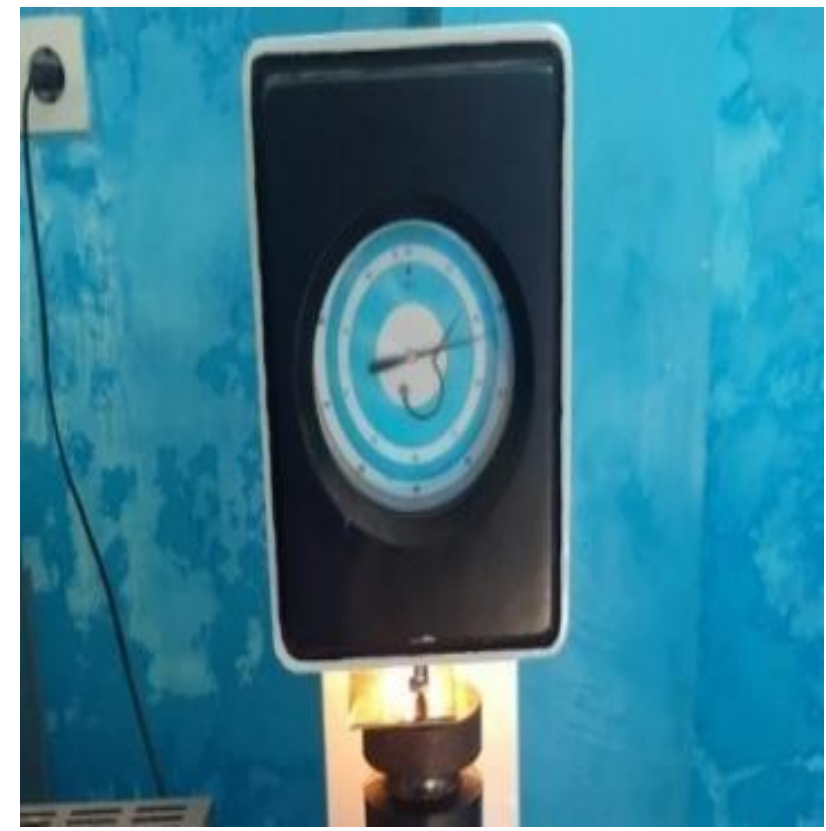

Gambar 3. Angka Hasil Penekanan

Data dari pengelasan tanpa media isolator didapatkan hasil data yang telah dilakukan uji kekerasan rockwel/ berat beban $100 \mathrm{Kgf}$,seperti tertera pada tabel 2 di bawah ini.

Tabel 2. Data tanpa media isolator

\begin{tabular}{|c|c|c|c|}
\hline Titik & & Logam Las / Satuan & HAZ / Satuan \\
\hline 1 & \multirow{11}{*}{$\begin{array}{l}\text { Sambungan Las } \\
\text { Tanpa Media } \\
\text { Isolator }\end{array}$} & $45 \mathrm{HRB}$ & $46 \mathrm{HRB}$ \\
\hline 2 & & 45 HRB & 47 HRB \\
\hline 3 & & $47 \mathrm{HRB}$ & $47 \mathrm{HRB}$ \\
\hline 4 & & 48 HRB & $46 \mathrm{HRB}$ \\
\hline 5 & & $46.5 \mathrm{HRB}$ & $46 \mathrm{HRB}$ \\
\hline 6 & & $47 \mathrm{HRB}$ & 46 HRB \\
\hline 7 & & $47 \mathrm{HRB}$ & $46 \mathrm{HRB}$ \\
\hline 8 & & $48 \mathrm{HRB}$ & $46 \mathrm{HRB}$ \\
\hline 9 & & $50 \mathrm{HRB}$ & $46 \mathrm{HRB}$ \\
\hline 10 & & $48 \mathrm{HRB}$ & $48 \mathrm{HRB}$ \\
\hline ata - Rata & & $42.96 \mathrm{HRB}$ & $46.4 \mathrm{HRB}$ \\
\hline
\end{tabular}

Media pendingin putih yang digunakan untuk mendinginkan atau penahan panas pada logam las, media yang digunakan udara yang memiliki angka kekerasan 42,96 HRB pada bagian las dan dibagian HAZ memiliki angka kekerasan 46,4 HRB yang lebih tinggi dibandingkan pada bagian logam las. Gambar 4 Menunjukan grafik nilai kekerasan pada logam las tanpa media isolator. 


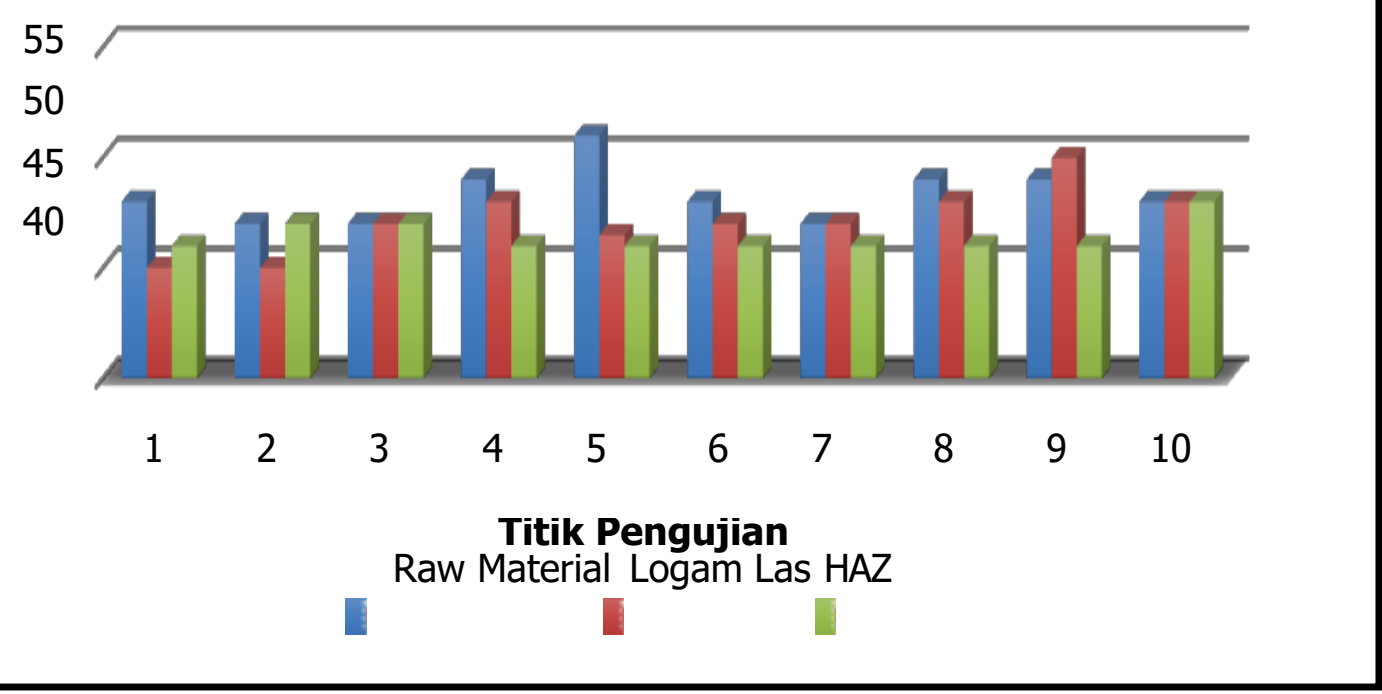

Gambar 4. Grafik Spesimen Tanpa Media Isolator dan HAZ

\subsection{Pengujian Hasil Las Dan Haz Dengan Serbuk Semen Putih}

Untuk mengetahui angka awal dari kekerasan bahan sebelum bahan diberi beban yang lebih berat pada Gambar 5 menunjukkan pemberian awal pada material diberi beban $10 \mathrm{kgf}$ dengan waktu lama penekanan 5 detik serta memberikan beban akhir sebesar $100 \mathrm{kgf}$ dengan lama waktu tunggu selama 5 detik seperti pada Gambar 6.

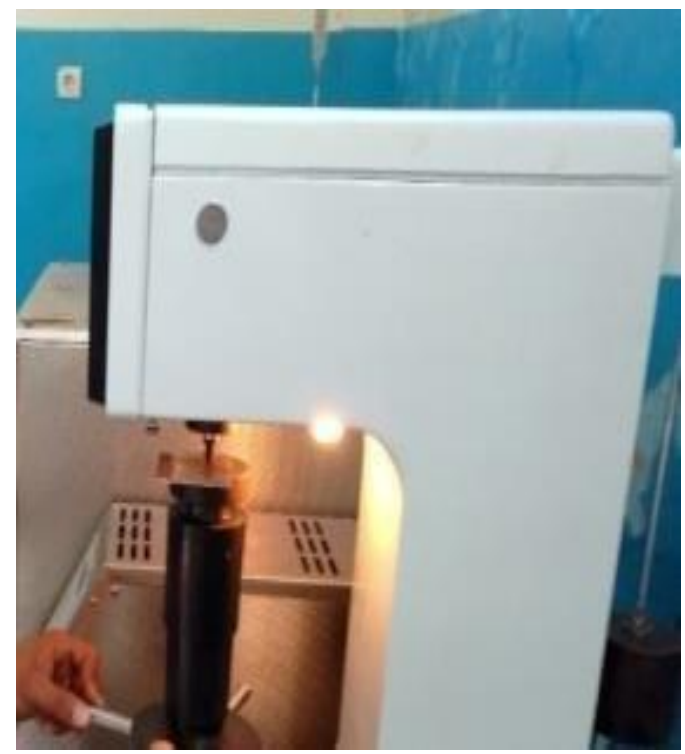

Gambar 5. Pemberian Beban Awal

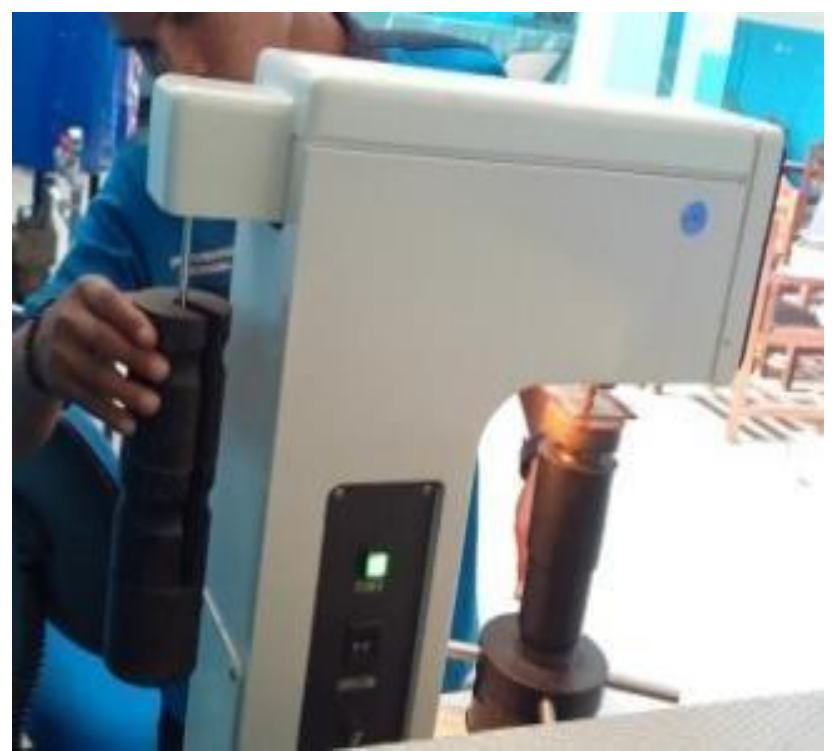

Gambar 6. Penambahan beban 
Data yang didapat dari pengelasan dengan metode pendingin serbuk semen putih telah didapatkan hasil data yang telah dilakukan uji kekerasan rockwel/ berat beban $100 \mathrm{Kgf}$ dapat dilihat pada tabel 3 di bawah.

Tabel 3 data serbuk semen putih

\begin{tabular}{|c|c|c|c|}
\hline Titik & & $\begin{array}{r}\text { Semen Putih/ } \\
\text { Satuan }\end{array}$ & $\begin{array}{c}\text { HAZ Semen Putih / } \\
\text { Satuan }\end{array}$ \\
\hline 1 & \multirow{11}{*}{$\begin{array}{l}\text { Sambungan las } \\
\text { dengan madia semen } \\
\text { putih dan bagian yang } \\
\text { terkena perlakuan } \\
\text { panas atau HAZ }\end{array}$} & $50 \quad \mathrm{HRB}$ & $49 \quad \mathrm{HRB}$ \\
\hline 2 & & $46.5 \mathrm{HRB}$ & $47 \mathrm{HRB}$ \\
\hline 3 & & 47 HRB & HRB \\
\hline 4 & & 46 HRB & 47 HRB \\
\hline 5 & & $45.5 \mathrm{HRB}$ & 48 HRB \\
\hline 6 & & 48 HRB & 47.5 HRB \\
\hline 7 & & 49 HRB & $48.5 \quad H R B$ \\
\hline 8 & & $47 \quad \mathrm{HRB}$ & 48.5 HRB \\
\hline 9 & & $47.5 \mathrm{HRB}$ & 49.5 HRB \\
\hline 10 & & $50 \quad \mathrm{HRB}$ & $50 \quad \mathrm{HRB}$ \\
\hline Rata-Rata & & $47.65 \mathrm{HRB}$ & 48.2 HRB \\
\hline
\end{tabular}

Nilai kekerasan pada sambungan las dengan media semen putih memiliki kekerasan 47,65 HRB yang lebih rendah dibandingkan dengan bagian HAZ yang memiliki kekerasan 48,2 HRB lebih tinggi. Semen putih mengandung C2S yang sulit terhidrasi dan tidak memiliki sifat panas. Jadi lebih cepat mendinginkan logam lasan. Semakin cepat pendinginan maka semakin meningkat angka kekerasannya. Gambar 7 menunjukan nilai kekerasan logam las dan HAZ dengan media semen putih. 
60

50

40

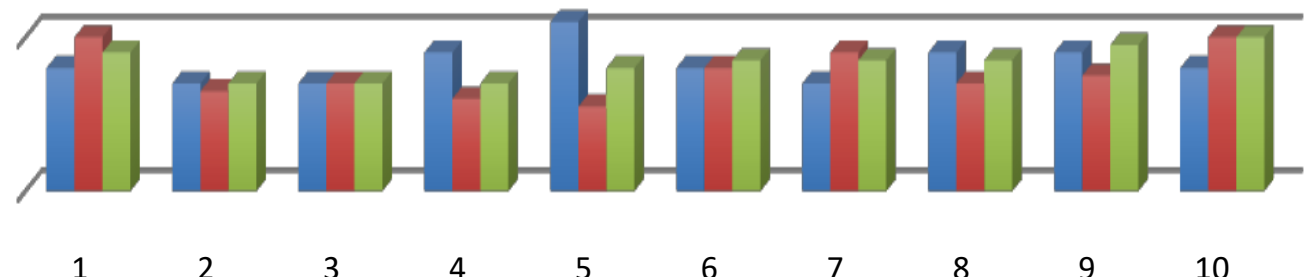

Titik Pengujian

Raw Material Logam Las HAZ

5

(1)

Gambar 7. Grafik Spesimen Semen Putih dan $H A Z$

\subsection{Perbandingan Hasil Las}

Hasil pengamatan dan pengumpulan data pada logam las yang didinginkan dengan media semen putih memiliki kekerasan yang lebih rendah dibandingkan dengan udara, karena pada saat pendinginan media semen putih lebih lama saat mendinginkan logam las.Seperti pada Gambar 8 tentang grafik perbandinagn logam las. Semakin lama pendinginan terjadi maka semakin rendah angka kekerasan logam. Jika semakin cepat proses pendinginan maka semakin keras pula logam tersebut. Ini membuktikan bahwa semen putih bahan isolator yang baik.

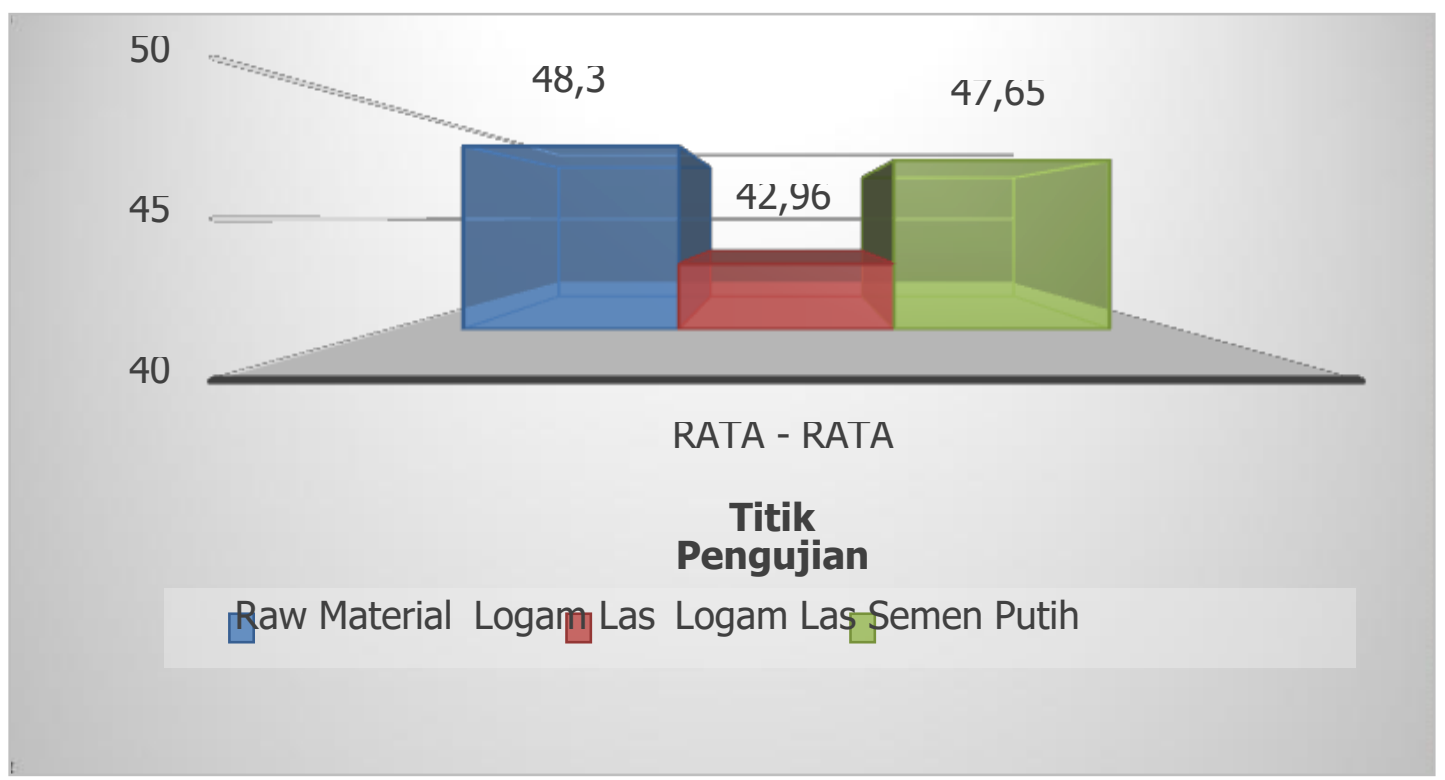

Gambar 8. Grafik Perbandingan Logam Las 


\subsection{Perbandingan Hasil Haz}

Jika dilihat dari fenomena diatas bahwa media semen putih angka kekerasannnya lebih rendah dibandingkan dengan udara,seperti yang tertera pada Gambar 9 di bawah ini.

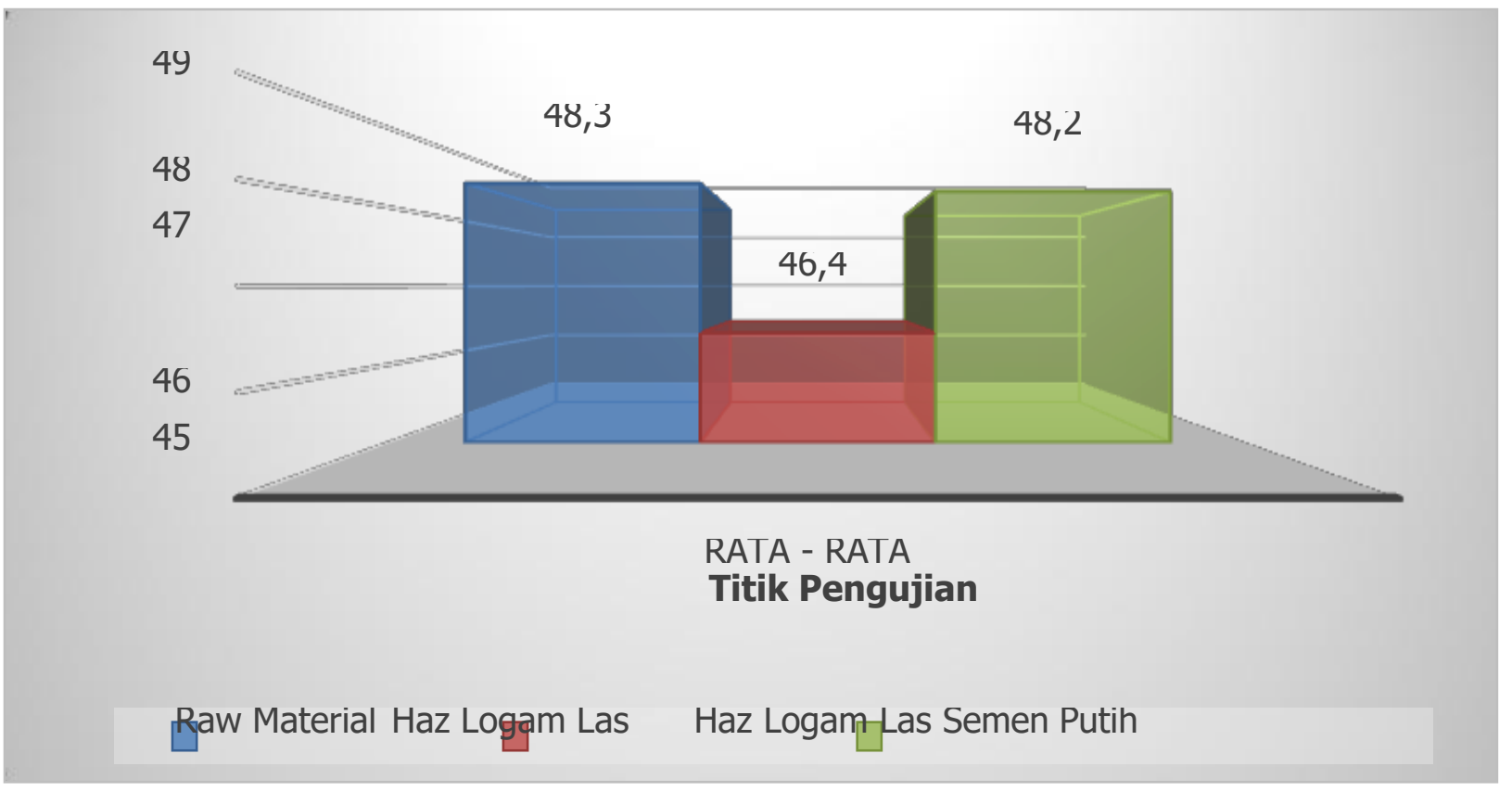

Gambar 9. Grafik Perbandingan $H A Z$

Berdasarkan grafik diatas, angka kekerasan logam, HAZ pendinginan udara adalah 46,4 HRB, logam HAZ pendinginan semen putih angka kekerasannya sebesar 48,2 HRB. Hal ini menunjjukkan angka kekerasan logam HAZ lebih keras dari pada logam lasan sendiri. Hal ini terjadi karena ketika pengelasan tersebut berlangsung, logam HAZ mengalami pemanasan tapi tidak sampai mencair seperti logam las, sehingga pendinginan yang terjadi pada daerah HAZ lebih cepat daripada pendinginan pada logam las. Hal ini yang menyebabkan kekerasan pada logam HAZ lebih tinggi dari pada logam lasannya sendiri.

Hal ini sesuai dengan yang disampaikan oleh Sriati Djaprie (1986:31) yang menyatakan bahwa pada proses yang mempengaruhi tingkat kekerasan baja adalah kecepatan pendinginannya karena makin cepat laju pendinginan maka kekerasan baja akan semakin tinggi. Hal ini juga sesuai dengan teori yang dinyatakan oleh Wiryosumarto dan Okumura (2004), bahwa logam HAZ bersebelahan langsung dengan logam las, jadi selama proses pengelasan logam HAZ mengalami siklus termal pemanasan dan pendinginan yang cepat. Ketika pengelasan tersebut berlangsung, logam HAZ mengalami pemanasan tapi tidak sampai mencair seperti logam las, sehingga pendinginan yang terjadi pada daerah HAZ lebih cepat daripada pendinginan pada logam las. Hal ini yang menyebabkan kekerasan pada logam HAZ lebih tinggi dari pada raw materials. 


\section{KESIMPULAN}

Pendinginan pengelasan metode SMAW dengan media serbuk semen putih memiliki kekerasan yang lebih keras, karena semen putih mengandung $\mathrm{C}_{2} \mathrm{~S}$ yang sulit terhidrasi,dengan dilakukan pengujian pada beberapa titik maka didapatlah hasil berupa nilai rata-rata dari spesimen raw material adalah 48,3 $\mathrm{HRB}$, pengelasan tanpa media isolator = 42,96 HRB dan $H A Z=46,4 \mathrm{HRB}$. Spesimen yang menggunakan serbuk. semen putih $=47,65$ HRB dan $H A Z=48,2 \mathrm{HRB}$, serta dari fenomena semen putih memiliki nilai kekerasan yang lebih tinggi dari pada udara, dimana nilai pada udara 46,4 HRB dan nilai pada semen putih lebih tinggi yaitu 48,2 HRB.

\section{REFERENSI}

[1] Abdul Hamid ( Januari 2016),"Analisa Pengaruh Arus Pengelasan Smaw Pada Material Baja Karbon Rendah Terhadap Kekuatan Material Hasil Sambungan," Jurnal Teknik Elektro Universitas Mercubuana, vol.7,no.1, pp.26 - 36.

[2] DA Tyagita,A Irawan (2016) " Kekuatan Tarik Hasil Penegelasan SMAW lat Baja ST 37 Dengan Pendinginan Liquid," Jurnal Ilmiah Inovasi,vol 16,no.3,pp.180 - 186.

[3] Fajar Riyadi,Dony Setyawan (2013),"Analisa Mechanical Dan Metallurgical Pengelasan Baja Karbon A36 Dengan Metode SMAW," Institut Teknologi Sepuluh Nopember (ITS) Surabaya ,-academia.edu.pp.1 - 12.

[4] Helanianto (2017), "Pengaruh Variasi Isolator Panas Pada Hasil Pengelasan Metode Smaw Terhadap Kekuatan Sambungan Logam Yang Dihasilkan,Jurnal Cyber- Techn. vol 11 no $02, p p .1-11$.

[5] Lawrence, H. Van Vlack (1986), Ilmu dan Teknologi Bahan. Terjemahan Oleh Sriati Djaprie. Jakarta : Erlangga.

[6] Li Ke Yan,Xue Dongfeng (2009 ),"Hardness of materials: studies at levels from atoms tocrystals," January 2009, Volume 54, Issue 1, pp 131-136.

[7] M.Zaenal Mawahib, Sarjito Jokosisworo, Hartono Yudo (Februari 2017),"Pengujian Tarik Dan Impak Pada Pengerjaan Pengelasan SMAW Dengan Mesin Genset Menggunakan Diameter Elektroda Yang Berbeda," Jurnal Ilmu Pengetahuan \& Teknologi Kelautan, Kapal, vol. 14, no. 1, pp. $26-32$.

[8] Malau,V (2003)., "Diktat Kuliah Teknologi Pengelasan Logam,"Yogyakarta,

[9] Riyanto (Februari 2015)," Analisa Perbandingan Material JIS SCM 415 dan JIS SCM 420 pada Proses Heattreatment, JTM Vol. 04, No. 1,pp. $31-37$.

[10] Saputra, Hendi and Syarief, Akhmad (2014), "Analisis Pengaruh Media Pendingin Terhadap Kekuatan Tarik Baja St37 Pasca Pengelasan Menggunakan Las Listrik," Jurnal Ilmiah Teknik Mesin Unlam, 3 (2). pp. 91-98. ISSN 2338-2236.

[11] Wiryosumarto,Harsono,Okumura Toshie,(2004), Teknologi Pengelasan Logam, Padnya Paramitha, Jakarta. 